\title{
Enzyme Therapy for Coeliac Disease: Is it Ready for Prime Time?
}

\author{
Hugh J. Cornell ${ }^{1}$ and Teodor Stelmasiak ${ }^{2}$ \\ ${ }_{1}^{1}$ RMIT University, Melbourne, \\ ${ }^{2}$ Glutagen Pty Ltd, Maribyrnong, \\ Australia
}

\section{Introduction}

Coeliac disease (CD) is a form of gluten intolerance in which the small bowel is damaged by proteins present in wheat, rye, barley and some varieties of oats (Mäki \& Collin, 1997). . These proteins cause severe damage to the duodenum and jejunum (villous atrophy) and can produce a variety of symptoms such as abdominal pain and cramping, bloating diarrhoea, nausea and lethargy.

The discovery of the disease by Dicke led to treatment by means of a gluten-free diet, which needs to be maintained for the rest of life (Dicke et al, 1953). If left untreated, severe malabsorption causes the loss of vital nutrients, resulting in conditions such as osteoporosis. In addition, anaemia and long-term immune and autoimmune mechanisms can induce lymphomas (van Heel \& West, 2006).

Diagnosis thus needs to be effected early in life and screening tests are available that are based on antibodies to tissue transglutaminase. If positive, biopsies are necessary to confirm the diagnosis of CD (Sollid, 2002).

In people of European descent about one in 100 people suffer from $\mathrm{CD}$, but the disease is considerably under-diagnosed. This is partly because, over the last two decades, the symptoms have changed and become more covert (van Heel \& West, 2006). Hence, it is vital that the correct diagnosis be made, taking advantage of serology and endoscopic biopsy, and if positive, a gluten free diet commenced. In addition, we recommend that enzyme supplementation be utilized in order to hasten repair to tissue and help to begin a greatly improved lifestyle (Cornell \& Stelmasiak, 2007).

The background to our work on enzyme therapy began with studies of etiology of CD and were essentially of a biochemical nature. Although treatment with a gluten-free diet had been hailed as a major breakthrough in patient management, the disease was still poorly understood and further studies were considered absolutely necessary. Like other studies of $\mathrm{CD}$, they were based on showing that the proteins in the gluten fraction of wheat were the causative agents (Anderson et al, 1952). Later, Frazer et al, (1959) showed that a peptictryptic digest of gluten was still toxic to patients with CD and obtained an indication that this toxicity was abolished by further treatment of the digest with an extract of hog mucosa, 
suggesting an enzyme deficiency was the cause of CD. Bronstein et al (1966) showed the peptic-tryptic-pancreatinic digests of the lower molecular weight group of proteins, called gliadin, were toxic in vivo. The following experiments were conducted to investigate the toxic factors present.

Fractionation of such a gliadin digest by ion exchange showed that it contained a fraction (Fraction 9) that was incompletely digested by small intestinal mucosa from children with coeliac disease in remission (Cornell \& Townley, 1973). Undigested residues showed up after electrophoresis of the mucosal digests.

Small intestinal mucosa from children with active coeliac disease was cultured in the presence of each fraction of the gliadin digest. Electron microscopy was used to observe the changes to the tissue. Fraction 9 was again seen as being different from the other fractions in that it prevented recovery of the tissue and thus was shown to be highly toxic (Townley et al.,1973).

Feeding tests using the xylose tolerance method in children showed that Fraction 9 was the only fraction to cause a reduction in urinary xylose excretion, thus confirming its toxicity in vivo (Cornell\&Townley, 1974).

Collaboration with Anderson and Rolles (Cornell \& Rolles, 1978) showed that there was a partial enzyme deficiency in a number of the first degree relatives of the coeliac probands, and helped explain the wide-range of symptoms observed in coeliac disease.

These studies confirmed that residues of undigested peptides were higher from coeliac patients in remission than from controls.

Further work was then focused on the structures of the peptides present in Fraction 9 and the types of mechanisms that might operate in $\mathrm{CD}$. Further collaboration in regard to other assays of toxicity was of the utmost importance as was the introduction of tests on synthetic peptides.

\section{The structures of the toxic peptides}

A considerable amount of research has been necessary to define the toxic peptides present in such a complex mixture as a gliadin digest. The basis for these experiments was finding that the toxicity of gliadin, in the form of a low molecular weight digest (approximately 1500 Daltons average) was concentrated in Fraction 9 (Cornell \& Townley, 1973). Hence it was decided to further fractionate Fraction 9 and perform amino acid analysis on the subfractions. Alongside these analytical experiments, it was, of course necessary to evaluate the in vitro toxicity of the various sub-fractions. This was achieved by the use of a screening assay based on the observation that rat liver lysosomes were disrupted by a peptic-tryptic digest of gluten (Dolly \& Fottrell, 1969). Using an assay based on lysosome disruption it was confirmed that Fraction 9 was the most toxic of the ion-exchange fractions obtained and this herewith gave confidence in the value of the assay as a screening test for toxicity (Cornell \& Townley, 1973b).

The justification for the use of the rat liver lysosome assay mainly came from the work of Riecken et al.(1966), who showed that human lysosomes lost their integrity in patients with active coeliac disease, but this integrity was regained on a gluten-free diet. The value of 
prednisolone in promoting recovery of mucosa in coeliac disease is known to be due to stabilization of lysosomal membranes (Weissman, 1966).

Fraction 9 was not only shown to be the most active fraction, but peptides remaining after digestion of Fraction 9 with remission coeliac mucosa still had an appreciable effect of lysosomal membranes, whereas those remaining after digestion of Fraction 9 with normal intestinal mucosa had only little effect (Cornell \& Townley,1973b).

The mucosal digestion experiments were repeated with an extract of porcine intestinal mucosa in comparison with remission coeliac mucosa and normal mucosa. Protection of the lysosomes was high with the porcine and normal human mucosal extracts but was low with remission coeliac mucosal extract (Cornell\& Stelmasiak, 2004).

These experiments showed the value of lysosomes in our understanding of an enzyme deficiency in coeliac disease. Most importantly, they have opened the way for enzyme therapy, which began with tests on animal intestinal extracts. Lysosomal assays thus form the basis of our assays for detoxification of gliadin.

The rat liver lysosome assay was employed in two different ways:

- The first way was to evaluate the toxicity of fractions of a gliadin digest and the synthetic peptides corresponding to the A-gliadin structure. Confirmation of the in-vitro toxicity of the latter in a chick assay (Mothes et al., 1985) could then be undertaken. For this purpose, the toxicity of each of the fractions was calculated from

$$
\mathrm{T}(\%)=\frac{Z-A}{Z} \times 100
$$

where $\mathrm{T}=$ toxicity

$\mathrm{Z}=$ absorbance at $410 \mathrm{~nm}$ after dilution with buffer and

$\mathrm{A}=$ absorbance at $410 \mathrm{~nm}$ after incubation at $37^{\circ} \mathrm{C}$ for 1.5 hours and then dilution with buffer.

Toxicity is thus a percentage reduction in absorbance caused by disruption of the lysosomes and has been shown to be highest in the case of Fraction 9, compared to all the other fractions of the gliadin digest (Cornell \& Townley, 1973b).

- $\quad$ The second way in which the assay was used was to evaluate the percentage protection offered by various animal and human mucosal extracts, plant extracts and commercial enzymes. Pre-incubation of the gliadin digest with enzyme solution, followed by incubation with lysosomes and dilution with buffer was necessary. Absorbance at $410 \mathrm{~nm}$ of this mixture (E) was then used to calculate $\mathrm{P}(\%)$ as follows:

$$
\mathrm{P}(\%)=\frac{E-A}{Z-A} \times 100
$$

P can also be calculated from

$$
P(\%)=\frac{T-T E}{T} \times 100
$$


where $\mathrm{T}_{\mathrm{E}}=$ Toxicity after pre-incubation with enzyme.

Mucosal digestion was carried out by homogenizing tissue in PBS $(30 \mathrm{mg} / \mathrm{mL})$ followed by filtration. The assay normally used $0.20 \mathrm{ml}$ of the filtrate per tube, $0.10 \mathrm{ml}$ of gliadin digest $(50 \mathrm{mg} / \mathrm{mL})$ and $0.10 \mathrm{ml}$ of a rat liver lysosome suspension. This latter suspension was of such concentration that $0.10 \mathrm{ml}$ when diluted with PBS gave an absorbance reading of 0.9-1.0 at $410 \mathrm{~mm}$ (Cornell \& Townley, 1973b).

The starting point for all subsequent studies was to determine the composition of the toxic peptides present in Fraction 9. This was achieved by HPLC of Fraction 9 on ODS Hypersil followed by amino acid analysis of the sub-fractions (Cornell et al.1992). The most active fractions, as determined by the lysosomal screening assay, were then subjected to amino acid sequencing. This led to the identification and amino acid sequence of two peptides one corresponding to residues 5-20 of A-gliadin from wheat (Fraction 13) and the other (Fraction 20) corresponding to residues 75-86 of A-gliadin, the A-gliadin sequence having been determined by Kasarda et al.(1994).

Sub-fraction 13 was shown to contain two peptides of similar amino acid composition and indicating about 16 residues in each. Both were close in composition to the peptide 5-20 of A-gliadin, which contains the PSQQ and QQQP motifs, seen to be important to toxicity by De Ritis et al. (1988).

Sub-fraction 20-1 (rechromatographed Sub-fraction 20) was shown to be identical to residues 75-86 of A-gliadin and specific amino acid deletions were useful in showing that toxicity in the chick assay was lost below the size of the octapeptide 77-84 (Cornell \& Mothes,1993). Peptide 75-84 still retained toxicity. Peptides within the sequence 75-86 appear to be immunogenic peptides, as shown by their ability to cause the release of gamma-interferon from red blood cells of patients with CD (Cornell et al., 1994).

Sealy-Voyksner et al (2010) have identified several peptides in gluten digests that are relevant to the immunological response in patients with $\mathrm{CD}$. Some of these correspond to segments of $a-$ and $B$-gliadins, and were close matches to those in previous studies on Agliadin (Mc Lachlan et al.2002). Importantly, one of these peptides contained the PQQPYP motif found in the active peptide 75-86 of A-gliadin (Cornell \& Mothes, 1993).

The work of De Ritis et al (1988), was an important finding as it enabled McLachlan et al (2002) to use a proteomics approach to investigate common sequences in wheat, rye and barley - the most toxic cereals to patients with CD - and compare them with oats (having questionable toxicity in $\mathrm{CD}$ ) and maize and rice (non-toxic cereals). They found that QQQP was present in a number of sequences in wheat, but QQQPS was also found in the non-toxic cereals, maize and rice. This led to the conclusion that the flanking amino acids were also important and extended motifs needed to be examined. When this was done it turned out that an extended motif common to wheat, rye and barley was QQQPFP. A shorter motif, QQQPF was also present in oats and may be present in the cultivars of this cereal which have been shown to have activity in some 'in-vitro' assays (Silano et al., 2006).

Regarding the PSQQ motif, proposed by De Ritis et al. (1988) the relevant extended motifs were FPSQQ, PSQQP, PFPSQQ and FPSQQP, but these were associated only with wheat and barley, not rye. 
The proteomics approach opened the way for looking at other motifs which may be associated with CD toxicity. Mention has already been made of HPLC of Fraction 9 and amino acid analysis of the fractions. These experiments showed that there were two subfractions which were toxic to rat liver lysosomes and that amino acid analysis and amino acid sequence determinations pointed to structures corresponding to residues 5-20 and 7586 of A-gliadin. The latter peptide proved to be the most abundant one of sequence RPQQPYPQPQPQ. It was thought that the key sequence in this peptide could be a four amino acid motif like QQPY, since the proteomic studies indicated that wheat, rye and barley all contained the extended motifs PQQPY and QQPYP which are both present in peptide 75-86(McLachlan et.al.,2002). Other searches had shown that peptide 31-49 of Agliadin (LGQQQPFPPQQPYPQPQPF) was toxic "in vivo" to patients with CD (Sturgess et al.1994). It can be seen that the extended ( 5 amino acid) sequences are also both present in this peptide. Fetal chick assays were also carried out on a series of peptides related to peptide 75-86(Cornell \& Mothes, 1993). These assays showed that all peptides in this region had appreciable toxicity except peptide 76-86 with an $\mathrm{N}$-terminal proline residue.

Regarding peptide 5-20 (VPQLQPQNPSQQQPQE), it is seen that not only the PSQQ motif, but the QQQP motif, is also present. The extended motifs PSQQQ, NPSQQQ and PSQQQ are found only in wheat. Again, it was found that searches for the four amino acid motif QPYP, resulted in matches for wheat, rye, barley, oats and the non-toxic rice indicating the need for using an extended motif.

The significance of this work only became apparent when the mucosal digestion studies of synthetic peptides and fetal chick assays were carried out. The use of the latter assay in connection with synthetic peptides prepared with selective amino acid deletions, showed that peptide 11-19 was the most active peptide within the sequence of 5-20. It was considerably more active than peptide 8-19, reported by Kocna et al. (1991), who used the same assay. The octapeptide 12-19, which contains motifs PSQQ and QQQP in overlapping sequence, was still toxic in the assay. This reinforced the view that sequences of eight-amino acids are large enough to retain toxicity, whereas the hexapeptide 13-18 is not (Cornell \& Mothes, 1993).

Peptide 11-19 gave higher amounts of residues after digestion with remission coeliac mucosa than were obtained with normal mucosa. Moreover, these residues still retained the serine residue, presumably associated the PSQQ motif, because the amino acid composition of the residues matched the octapeptide sequence 12-19, QNPSQQQPQ (Cornell \& Rivett, 1995). It is interesting that peptide 206-217, has been shown to be toxic in vivo (Mantzaris \& Jewell, 1991). Its sequence of LGQGSFRPSQQN contains the PSQQ motif, which may be a problem with digestion by coeliac mucosa.

Mucosal digestion and amino acid analysis of residues from peptide 75-86 were also very informative (Cornell, 1998). Again, like peptide 11-19, digestion with remission coeliac mucosa was not complete and residues corresponding to octapeptides were obtained. These residues seemed to correspond to peptide 77-84 (QQPYPQPQ) which was shown to be toxic in the fetal chick assay. Such residues also contain the QQPYP extended motif, suggesting that an enzyme deficiency in remission coeliac mucosa is the reason why these undigested residues remain and also why the extended motifs present in residues 12-19, QNPSQQQPQ (from peptide 11-19) and 77-84, QQPYPQPQ (from peptide 75-86) both contain the extended amino acid sequences corresponding to the three most toxic cereal proteins. 
With regard to the activity of other peptides of A-gliadin, Vader et al.,(2002) have shown that gluten-specific T-cell responses in HLA-DQ2 positive adult coeliac patients are directed at multiple peptides of gliadin and glutenin. An interesting example is peptide 56-68 of Agliadin (LQLQPFPQPQPY). By the criterion of activation of coeliac intestinalCD4+ T-clones (Halstensen et al., 1993), it is the dominant epitope, yet it is not able to cause damage in vitro. Another two examples are the A-gliadin peptides 31-43 and 31-49. The former peptide does not activate coeliac intestinal CD4+ T-clones (McAdam \& Sollid, 2000). Peptide 31-49 (LGQQQPFPPQQPYPQPQPF) which is toxic in vivo (Sturgess et al., 1994) has the De Ritis motif QQQP and the tyrosine motifs QQPY and QPYP, both of which are associated with coeliac-toxic cereals (McLachlan et al., 2002). However, peptide 31-43 has only the QQQP and QQPY but not QPYP, so the latter may have great importance in toxicity. Like peptide 31-49, the 33-mer peptide of alpha-2 gliadin (Shan et al.,2002) also has the PYPQ motif.

Toxic action seen on fetal rat jejunum, but not on mature jejunum, is consistent with development of protective enzymes or immune mechanisms. Experiments in vitro production of interferon indicated that the serine-containing peptides, like peptide 11-19 of A-gliadin, were weakly immunogenic (but potent in their cytotoxicity) compared with the tyrosine-containing peptides like peptide 75-86 of A-gliadin (Cornell \& Wills-Johnson, 2001). Other workers (McAdam \& Sollid, 2000; Shan et al., 2002) have reported immunogenic peptides containing tyrosine. Peptides 57-73 of A-gliadin and 57-89 of a-2 gliadin do not have PSQQ or QQQP motifs, but the latter has the QPYP motif common to all three coeliac toxic cereals (McLachlan et al., 2002).

Secondary structural differences in the peptides 11-19 and 75-86 have been suggested by molecular modelling. This work indicates that peptide 11-19 favours an a-helical structure, whereas peptide 75-86 has high $\beta$-turn content Similarly, peptides in an avenin from oats, which also appear to be highly immunoreactive, have been shown to have a high $\beta$-turn content using circular dichroism(Alfonso et al.,1998).

\section{Etiology of coeliac disease}

Studies of possible enzyme deficiency have been rewarding, in that, using different techniques, all the results have pointed to two particular peptides from A-gliadin that seem to have different modes of action in regard to their toxicity, yet both are incompletely digested by remission coeliac mucosa (Cornell \& Rivett,1995; Cornell,1998).

An enzyme deficiency has been indicated not only from studies of native gliadin but also from studies using synthetic peptides. At this point it would be of benefit to readers to list the findings which support an enzyme deficiency.

a. One fraction of a gliadin digest (Fraction 9) was incompletely digested by small intestinal mucosa from patients with $\mathrm{CD}$ in remission. This fraction was completely digested by small intestinal mucosa from normal individuals as were all the other fractions of the digest by mucosa from normal and those with CD (Cornell \& Townley, 1973).

b. Cultures of small intestinal mucosa from patients with active CD improved after 24 hours in media containing fractions other than Fraction 9 or in the absence of gliadin. This was in complete contrast to tissue from patients in the presence of Fraction 9. Tissue from normal individuals was not damaged, except to a small extent with 
Fraction 9. Electron microscopy was thus able to differentiate the damage caused by the presence of toxic gliadin peptides in the culture medium (Townley et al., 1973).

c. Using the tanned red blood cell technique, it was shown that antibodies against the fractions from ion exchange of the gliadin digest were highest against Fraction 9, suggesting that in patients with active CD, undigested peptides from Fraction 9 had mounted a significant immune response, compared with other fractions, which had presumably been better digested (Cornell,1974).

d. The xylose tolerance test showed that in children with CD in remission, some damage to the small intestine was indicated by reductions in levels of xylose excretion in their urine after ingestion of Fraction 9. No significant changes in urinary xylose were seen with the other fractions when combined (Cornell \& Townley, 1973).

e. Fraction 9 displayed high activity in a fetal chick assay and was shown to contain two active peptides, one corresponding to residues 5-20 and the other to residues 75-86 of Agliadin (Cornell et al., 1992). When these peptides were subjected to specific deletions of amino acids it was found that the most active peptide was the nonapeptide 11-19 while the dodecapeptide 75-86 was seen to be close to the maximum activity in this group of peptides (Cornell \& Mothes,1993,1995).

f. Coeliac mucosal digestion of each of these peptides showed that undigested residues of octapeptides were obtained in greater amounts than those obtained from digestion with mucosa from normal individuals (Cornell \& Rivett, 1995; Cornell, 1998).

g. Importantly, these undigested octapeptides were found to contain sequences of amino acids found by ourselves and others to be associated with toxicity (De Ritis et al.1988; McLachlan et al., 2002).

The connection between the most active fraction and undigested peptide residues being found in the same fraction indicates that the reason for this toxicity is due to insufficient activity of an enzyme in patients with CD. This proposal was first put forward by Frazer et al. (1959) on the basis that patients on a gluten-free diet relapsed after being fed a peptictryptic digest of gluten, but this did not happen when the gluten digest was subjected to further digestion with a hog intestinal extract.

It must be said that apart from our work and that of our collaborators, little else has been contributed to support an enzyme deficiency in CD. Perhaps some commonality is seen in the work on a 33-mer peptide of a-2gliadin, which was observed to be difficult to digest (Shan et al., 2002).These undigested peptides have significant immunogenicity which are thought to be responsible for toxicity, but so far, no toxicity data have been presented. Current work in this area is directed towards an understanding of the type of enzyme which appears to be missing or defective in $\mathrm{CD}$. One way of gaining this information is by examining the structures of peptides which remain after coeliac mucosal digestion. The other way is to examine the types of peptides that are the most effective for digesting the gliadin down to small fragments which are no longer toxic in the assay employed. These approaches will be discussed in Sections 5 and 6 of the chapter.

\section{A unified theory of CD}

Quite often, CD is referred to an autoimmune disease, meaning that the body, by mistake, produces antibodies that damage its own tissues (Maki, 1996). Although antibodies are produced in patients with CD to tissue transglutaminase (tTG), which potentiates the action 
of dietary gluten, the source of the problem is a group of proteins which are foreign to the body and if these are not broken down to amino acids and small peptides, an immunological response will be mounted and tissue will be damaged. If the proteins are broken down to amino acids and small peptides, the tissue will remain in a normal and healthy state (Cornell \& Stelmasiak, 2007).

These harmful proteins are present in wheat, barley and rye and to a much smaller extent in oats. The wheat gluten contains two major groups of proteins, referred to as glutenins and gliadins. The latter group contains proteins of lower molecular weight $(\approx 30,000$ Daltons $)$ and are regarded as being the more harmful to those with CD. Most work has been done on these gliadins, not only because of their higher toxicity, but also because they are simple chain proteins and can be readily extracted from gluten or flour by $70 \% \mathrm{v} / \mathrm{v}$ ethanol (Mothes et al., 1999). They are referred to as prolamins. Prolamins from rye are called secalins, those from barley as hordeins and those from oats as avenins.

Some humans are born with a genetic predisposition to $\mathrm{CD}$ which may become obvious after exposure to dietary gluten, as when an infant is introduced to solid foods. The HLA typing with the genes referred to as DQ2 and DQ8 and genetic testing is useful for excluding a diagnosis of $C D$. However, only about $3 \%$ of people with either or both these genes will develop CD. The prevalence of HLA-DQ2 alone is about $25 \%$ in the North European population yet only about $1 \%$ has $\mathrm{CD}$, suggesting that additional genes are involved in CD (Kagnoff, 2007). Mäki and Collin (1997) reported that more specific factors, probably non-HLA genes are involved. Both genetic and environmental factors appear to play a role in development of $\mathrm{CD}$.

The older theory of an enzyme deficiency in CD must be given serious consideration because it is hard to imagine what type of substance in a hog intestine extract, other than an enzyme, can result in detoxification of a gluten digest. (Frazer et al., 1959). Moreover, the work summarised in Section 3 by the writers carries some weight insofar as certain toxic peptides in A-gliadin seem not to be completely digested by mucosa from children with CD in remission. Strengthening this even more is the finding of motifs of amino acids from two peptides which appear in the residues from mucosal digestion of children with $C D$ in remission that we and others have shown to be associated with the toxicity of gliadin

The concept of an enzyme deficiency is more plausible than the proposal that proline-rich epitopes are exceptionally resistant to enzymatic processing (Hausch et al., 2002). 'In vitro' mucosal digestion with small intestinal homogenates from normal individuals show consistently lower amounts of peptide residues from toxic peptides compared to residues from coeliac mucosal digestion. However if the amounts of peptides used are excessive, compared with mucosal dry matter, one would expect more residual peptides from the normals. For those interested in the historical overview of the assays and toxicity studies, the reader is referred to an older review (Cornell, 1996).

Coupled with an enzyme deficiency is the need to recognise the plethora of immunological reactions that appear to be responsible for the pathology of $\mathrm{CD}$. We fully affirm the importance of immunological reactions in the pathogenesis of $\mathrm{CD}$ as proposed by Falchuk and Strober (1974). However, Biagi et al. (1999) dispute that the pathology is the result of abnormal presentation of gliadin. We contend that these pathogenetic mechanisms are the result of partially digested gliadin (or other toxic cereal peptides) that accumulate in the 
small intestine as the result of an enzyme deficiency. The immune response might be magnified by prior cytotoxic action. Experiments with two types of toxic peptides we have described tend to verify this view.

Several hypotheses have been proposed to account for the susceptibility of certain individuals to CD. Two major hypotheses have been referred to as the Enzymopathic (enzyme deficiency) Hypothesis (Frazer et al., 1959) and the Immunological Hypothesis (Falchuk \& Strober, 1974). A third hypothesis is based on a defect in the permeability of the intestinal mucosa (Bjarnason \& Peters, 1983).

The evidence for damage to tissue as a result of immunological mechanisms is overwhelming but the argument that it represents an aberrant reaction because of abnormal presentation of gliadin is less convincing (Biagi et al., 1999). The modern view is that HLA class II molecules in antigen-presenting cells expose processed peptides to immunocompetent T-cells thereby triggering pathogenesis (Sollid, 2002).T-lymphocytes respond by releasing cytokines which cause inflammation and damage of enterocytes and other cells in the small intestine.

Vader et al (2002) studied gluten specific T-cell responses in HLA-DQ2 positive adult patients with $C D$ and showed that they were directed at multiple peptides derived from gliadin and glutenin. There is a broad spectrum of sensitivity to gluten in patients with CD and this can be explained partly by multiple levels of immune regulation (Schuppan \& Hahn, 2002) and partly by enzymatic processes governing the extent of digestion of gliadin peptides (Cornell \& Rolles, 1978).

Regarding the hypothesis of permeability defect in the intestine mucosa ("Leaky Gut" syndrome), the general argument is that there is increased permeability of the epithelium. One group claims that this is caused by a myosin variant and leads to increased antigen presentation(Monsuur et al.,2005) whilst another group claims that sustained release of zonulin occurs, concomitant with an increase in permeability (Drago et al.2006). The zonulin release was less in normals, suggesting better digestion of gliadin occurred.

The writers have proposed a "Unified Hypothesis of CD" (Cornell \& Stelmasiak, 2007) to account for the specific causative effects of gluten, which cannot be explained simply by saying that gliadin peptides are difficult to digest. Certainly, there has been some evidence to suggest that individuals other than those with $\mathrm{CD}$ have problems caused by glutencontaining food (Jones et al., 1982). The fact of the matter is that the majority of people do not encounter this problem, except for some first degree relatives, who have been shown to have partial deficiency in regard to their ability to digest gluten completely (Cornell \& Rolles, 1978). The etiology of CD has many similarities to that of dermatitis herpetiformis, except that the manifestation of this condition is the formation of a rash and itchiness (Fry, 1992). Both are quite different in etiology to wheat allergy.

It raises the important point that some gliadin peptides may not inflict damage to cells until they are modified in some way. Mölberg et al. (1998) have shown that tissue transglutaminase appears to modulate the reactivity of gliadin-specific T-cells. This effect is mediated by a specific deamidation of gliadin peptides which binds them strongly to DQ2 molecules and allows recognition by certain T-cells. It is an important example of enzymatic modification of antigens that results in activation of pathological processes. 
Returning to the basic etiology of $\mathrm{CD}$, the writers maintain that there are multiple peptides in a peptic-tryptic-pancreatinic digest of gliadin that require a specific enzyme for complete digestion to harmless peptides. This enzyme is deficient or defective in individuals with CD. The enzyme attacks peptides that contain certain sequences of amino acids that are present in the three coeliac-toxic cereals, wheat, rye and barley. Without this enzyme patients with $\mathrm{CD}$ are unable to digest the gliadin peptides and damage to the small intestine mucosa ensues (Cornell \& Stelmasiak, 2007).

Two different types of active peptides have been discerned and the use of synthetic peptides of A-gliadin have made it possible to say that a group of serine-containing peptides such as 11-19 of A-gliadin have displayed potent cytotoxicity, while those such as tyrosinecontaining peptide 75-86, have potent immunogenicity (Cornell\&Wills-Johnson,2001).It is because of the fact that both these peptides are not digested by coeliac mucosa down to small harmless peptides, but instead resist digestion past the octapeptide stage, that we invoke the concept of damage both by cytotoxic and immunologic mechanisms (Cornell \& Stelmasiak,2007). The latter are suggested from their ability to produce interferon- $\gamma$ from red blood cells from patients with CD (Cornell et al.,1994) This is not so for the serinecontaining group of toxic peptides. Hence the writers have proposed a hypothesis which combines the two main theories, henceforth referred to as the Unified Hypothesis (Cornell \& Stelmasiak, 2007). The etiology and pathogenesis of CD are closely linked in complex events and this term seems to be a satisfactory way of explaining all of those events according to present day knowledge.

Other workers have pointed out the difficulty of digesting certain proline-rich peptides which can involve immunological reactions leading to intestinal damage. Hausch et al. (2002) comment on immunodominant epitopes that are considered difficult to digest because of the low activity of enzymes capable of N-terminal and C-terminal attack on proline residues (DPPIV and pancreatic endoproteases respectively). These epitopes are probably more important from the point of view of their particular key amino acid sequences, particularly ones that contain tyrosine, rather than their high proline content. The bioactivity of wheat and problems with the digestion of some of its components in CD have been pointed out (Cornell \& Hoveling, 1998). The 33-mer peptide of a-2 gliadin (Shan et al., 2002) is also difficult to digest and again, the repeating sequences containing proline, tyrosine and glutamine are probably of importance to its immunogenicity. From a clinical point of view, they also provide the rationale for the application of enzyme therapy. Sollid offers an explanation that proline has a dominant role in the specificity of tissue transglutaminase and could facilitate binding to the above 33-mer fragment (Sollid, 2002).

\section{The basis of enzyme therapy}

The elucidation of structures in gliadin that are resistant to digestion by remission coeliac mucosa has provided a promising basis for treatment, providing the amount of gluten ingested is not excessive. The way in which this could be evaluated was offered by the use of the rat liver lysosome assay, based on the principle that the lysosomes are disrupted by toxic gliadin peptides. If the gliadin is detoxified by an enzyme capable of digesting the peptides responsible for damage to the lysosomes, that enzyme could form the basis of suitable therapy for patients with CD. 
It was kept in mind that, to be effective therapy, the product would have to be able to counteract 50mg of gluten/day (Catassi et al.2007). Hence there would be no way of achieving high degrees of protection unless the patients remained on a nominal gluten-free diet in order to achieve a degree of protection and used enzyme therapy as an adjunct treatment, i.e., as a safeguard.

Another use of the rat-liver lysosome assay, which throws direct light on the enzyme deficiency in $\mathrm{CD}$, is the way it was used to show that there was residual activity in Fraction 9 after incubation of small intestinal mucosa from children with CD in remission. In five experiments, the mean reduction in absorbance was $45 \%$ for coeliac mucosa and $23 \%$ for normal mucosa. Controls without Fraction 9 registered 18\%, close to the normal mucosa. Thus, there appears to be incomplete digestion of Fraction 9 in those with CD compared with normals $(\mathrm{p}<0.001)$ (Cornell \& Townley, 1973b).

This conclusion had also been indicated by toxicity studies with fetal rat mucosa (Cornell et al., 1988) and gave confidence in the use of lysosomes as a screening test. Similarly, good correlations between the lysosome screening test and results of fetal chick assay were obtained (Cornell \& Mothes, 1995).As an animal model for studies of CD small intestinal tissue from fetal animals has been very useful, presumably because these animals do not have fully developed protective enzyme systems. This, of course, is completely in agreement with the idea of defective digestion being a key component of tissue damage by gliadin peptides.

The authors embarked on a program to study adult animal intestine with a view to determining if complete digestion of toxic gliadin peptides could be achieved and thereby used as a means of providing the missing or defective enzymes in patients with $C D$. In these studies of animal intestinal mucosa, the authors showed that no significant toxic peptide residues remained after digestion of the gliadin digest with the normal human, pig, cow and sheep intestinal mucosa, whereas toxic residues were obtained after incubation with remission coeliac mucosa. Highest degrees of protection (85-90\%) against gliadin were offered in the lysosomal assay by the pig and cow extracts, followed by human and sheep (70-76\%). By contrast, remission coeliac mucosa offered only $15 \%$ protection, not very different from the controls without mucosa (Cornell \& Stelmasiak, 2004).

These results led to our first experiments with animal mucosa in which we decided to investigate the use of pig mucosal extracts for enzyme therapy in CD. It was of great importance to note that digestion by the intestinal mucosa of these animals was comparable to that by normal human mucosa and far more complete than that seen in patients with CD in remission. These animals have been ingesting various forms of gluten for millions of years longer than have humans and have evolved efficient digestive systems. Some humans are well behind in this aspect and conjecture on this matter is strengthened by a further group of individuals who have varying degrees of gluten intolerance (Van Heel \& West, 2006).

Pig intestinal mucosa was chosen for a series of investigations designed to show that the active principle in this mucosa was an enzyme. It was therefore necessary to begin with 
large quantities of pig mucosa and refine it to the extent of producing enough active enzyme to be characterized and possibly identified.

The evaluation of products from all stages of the purification were monitored by the rat liver lysosome assay (refer Section 2) using a 2 hour at $37^{\circ} \mathrm{C}$ period of incubation of the fraction of pig mucosa with the gliadin digest before testing residual toxicity against the lysosomes. When the enzyme was effective, the residual toxicity was low; hence high values of protection $(\mathrm{P})$ were obtained.

The first stage of refinement involved the use of an ion-exchange resin. Ion exchange resins were considered favourably because their bead form allows high flow rates and they can be readily regenerated using sodium hydroxide. Pilot scale experiments using filtered extract from $4 \mathrm{~kg}$ pig intestinal mucosa yielded a product enriched in gliadin detoxifying enzymes from the use of the weakly basic Amberlite anion exchange resin, IRA95.

The active principle in the pig intestinal mucosa was found to be bound by the ion-exchange column at $\mathrm{pH} 7.5$ and could be eluted by phosphate buffer of $\mathrm{pH} 5.0$ containing $0.3 \mathrm{~mol} / \mathrm{L}$ sodium chloride. The eluate was desalted by membrane filtration and freeze dried. A refined enzyme extract was obtained as a fawn-coloured powder in yields of 3-4\% on freezedried mucosa extract.

Further fractionation using laboratory-sized columns of the weakly acidic (carboxymethyl) ion exchanger CM Sephadex C50, were used to prepare more enriched fractions. In this case, the most enriched fraction was obtained by raising the $\mathrm{pH}$ of the phosphate eluting buffer $(0.05 \mathrm{~mol} / \mathrm{L})$ and applying a linear salt (sodium chloride) gradient to $0.3 \mathrm{~mol} / \mathrm{L}$. The most active fraction (Fraction 4 ) eluted at $\mathrm{pH} 6.2$ and $0.20 \mathrm{~mol} / \mathrm{L}$ sodium chloride.

The specific activity of each of the most active fractions was calculated from the results of the rat liver lysosome assay. Results of these evaluations are shown in Table 1 . Note that specific activity is calculated from protection (\%) offered per mg sample.

\begin{tabular}{lc}
\hline Sample & Specific Activity (P/mg) \\
\hline Crude enzyme extract & 12 \\
Fraction from Amberlite IRA 95 & 17 \\
Fraction 4 from CM Sephadex C-50 & 34 \\
\hline
\end{tabular}

Table 1. Specific activity of pig extract and crude fractions thereof

Other enzyme levels determined on Fraction 4 were protease levels by the benzoylarginine ethyl ester (BAEE) method, which is a good measure of total protease levels (Arnon,1970) Refer Table 2.

PEP levels in Fraction 4 were carried out using Z-gly-pro-p-nitroanilide ( Kocna et al., 1980). Crude pig extract showed levels of $6.4 \times 10^{-4} \mathrm{U} / \mathrm{mg}$ and this was increased to $2.1 \times 10^{-3}$ $\mathrm{U} / \mathrm{mg}$ after ion exchange on Amberlite IRA 96. Pure PEP (Seikagu, Japan) has a specific activity of $20 \mathrm{U} / \mathrm{mg}$ so the above levels showed that PEP was not an important contributor to activity, as measured by the lysosome assay.

An important finding was that prolidase activity, measured by the ability of the enzymes present to hydrolyse Ac-Pro-Gly was $0.025 \mathrm{U} / \mathrm{mg}$ in the crude extract while Fraction 4 was $0.06 \mathrm{U} / \mathrm{mg}$ (Cornell et al., 2010). 
Neither the crude extract nor the material absorbed on IRA 95 contained any significant amounts of enzyme activity measured according to the BAPNA (benzoylarginine pnitroanilide assay) (Gravett et al., 1991). This assay was used extensively in studies of activity in papaya oleo-resin (see Section 6).

\begin{tabular}{cccccc} 
Fraction No & $\begin{array}{c}\text { Yield } \\
(\%)\end{array}$ & Elution Conditions & $\begin{array}{c}\text { RLL assay } \\
(\mathrm{P} \%)^{*}\end{array}$ & $\begin{array}{c}\text { BAEE assay } \\
\mathrm{U} / \mathrm{mg}\end{array}$ & $\begin{array}{c}\text { PEP assay } \\
\mathrm{U} / \mathrm{mg}\end{array}$ \\
\hline 1 & 17.7 & unabsorbed & 45 & 0.10 & $4.3 \times 10^{-4}$ \\
2 & 5.2 & $\begin{array}{c}\text { change of } \mathrm{pH} \\
\text { change of } \mathrm{pH}\end{array}$ & 51 & 0.45 & $5.6 \times 10^{-5}$ \\
3 & 7.3 & $\begin{array}{c}0.10-0.20 \mathrm{~mol} / \mathrm{L} \\
\mathrm{NaCl}\end{array}$ & 90 & 0.31 & $8.0 \times 10^{-5}$ \\
4 & 7.4 & $\begin{array}{c}0.25 \mathrm{~mol} / \mathrm{L} \mathrm{NaCl} \\
5\end{array}$ & 35 & 0.10 & $5.8 \times 10^{-5}$ \\
6 & 9.7 & $\begin{array}{c}0.25-0.50 \mathrm{~mol} / \mathrm{L} \\
\mathrm{NaCl}\end{array}$ & 18 & 0.42 & $1.0 \times 10^{-5}$ \\
Starting & - & - & 68 & 0.78 & $1.8 \times 10^{-5}$ \\
Extract & - & & & & \\
\hline
\end{tabular}

*4mg fraction/assay tube

Table 2 . The results of activity and enzyme assays on fractions obtained by chromatography of the refined pig intestinal extract on CM Sephadex C-50 Column $(3.2 \times 20 \mathrm{~cm})$.

Fraction 4 was digested with trypsin and submitted for mass spectrometric fragmentation analysis but the only known protein found was pig albumin which has a molecular weight of $68 \mathrm{KDa}$, similar to that of the active enzyme produced during processing, even though temperatures were held at $5^{\circ} \mathrm{C}$. Without processing, the active enzyme in fresh pig extract is in the range of $120-170 \mathrm{kDa}$ obtained using Sephacryl S300, but Fraction 4 appears to have a very broad peak of activity between 50 and $80 \mathrm{kDa}$, which explains the contamination with pig albumin. No matches were obtained between the analysed sequences of the enzyme and the library of known pig enzymes. Specific activities of the higher $(80 \mathrm{kDa})$ and lower $(50$ $\mathrm{kDa}$ ) fractions on Sephacryl S-300 were 90 and 36 respectively, higher than the result (17) for the starting material.

Fraction 4 was further purified using size exclusion HPLC on Bio Sep SEC-S2000 in 0.05 mol/L phosphate buffer, $\mathrm{pH}$ 6.8. The column allowed applications of up to $3 \mathrm{mg}$ of sample. Highest activity was obtained in fractions that corresponded to molecular weight in the range $60-100 \mathrm{kDa}$. By absorbance at $214 \mathrm{~mm}, 6$ peaks were obtained, with the highest lysosomal activity in the range corresponding to peaks 2 and 3 . Some autolysis of the enzymes may have occurred during processing. These results are in agreement with the size exclusion experiments using Sephacryl S-300 (refer Table 2).

Estimates of specific activity on the fractions of highest lysosomal activity are in the range 180-220. This has allowed partial sequencing of active enzymes but the samples were not pure enough to show significant homology between the active enzyme and known enzymes present in the pig.

Fractionation of pig small intestine extract has been useful for characterising the active enzyme, according to monitoring with the rat liver lysosome assay. Among these can be listed: 


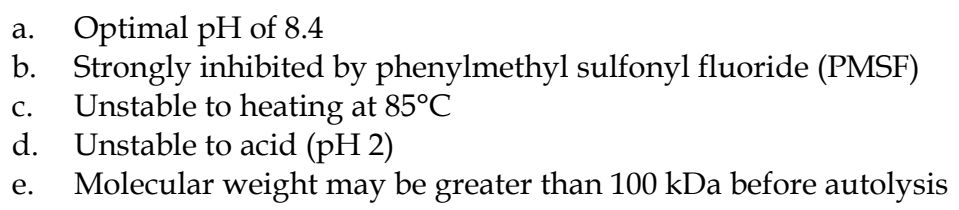

The identity of the enzyme in pig is likely to be similar to that of the missing enzyme in humans. It seems to fit the general description of a prolidase and appears to attack coeliacactive peptides on the N-terminal side of proline residues and is a necessity for digesting key motifs associated with toxicity that contain proline. Hence the enzyme is likely to be an imino-oligopeptidase, a proline specific enzyme not implicated in detoxification of gliadin up to this time.

In conclusion, an enzyme capable of detoxifying gliadin was found in pig intestinal mucosa and appears to be a prolidase. It can be partially separated from prolyl endopeptidase (PEP) which has less activity than the prolidase in the rat liver lysosome assay, considered to be relevant to measurement of protection against gliadin toxicity.

Enrichment of the prolidase can be achieved by elution of higher salt concentration in phosphate buffers on weakly acidic cation exchanges or by reason of its higher molecular weight. The prolidase has a higher $\mathrm{pH}$ optimum (8.4) compared with PEP (7.5).

Because of the ability of the prolidase to attack the N-terminal side of proline residues, it is ideal for disrupting toxic residues common to wheat, rye and barley such as QQQP, QQPYP and PQQPY. By this means, toxicity of peptides derived from these three cereals is able to be curtailed and small amounts of the cereals will be able to be tolerated. PEP attacks these sequences on the C-terminal side of proline residues, which may not be as effective in reducing toxicity. Even with sequences such as 11-19 of A-gliadin (QNPSQQQPP), that appear to be only present in wheat, it was observed(Cornell\&Rivett,1995) that the N-P bond remained intact, which would not be the case after attack by a prolidase.

\section{Strategies for treatment of CD}

Since the publication of the first clinical trial of enzyme therapy, other groups have also contributed to knowledge in this area. Shan et al. (2002) have shown that a 33-mer T-cell stimulatory peptide, which appears to cause difficulties in digestion by normal digestive enzymes, can be degraded by prolyl oligopeptidase from Flavobacterium meningosepticum. Others have shown that this enzyme has only limited efficiency in the detoxification of gliadin peptides in CD (Matysiak-Budnik et al., 2005). Furthermore this enzyme is not deficient in remission coeliac mucosa, as one would expect if it were a key factor (Donlon \& Stevens, 2004).

Other types of enzymes which have been investigated for use in enzyme therapy are those from Aspergillus niger. Stepniak et al. (2006) have identified a prolyl endopeptidase (AN$\mathrm{PEP}$ ) from A.niger which was able to degrade T-cell stimulatory peptides in vitro under conditions like those in the gastrointestinal tract. Its action was considerably faster than the prolyl endopeptidase from Flavobacterium meningosepticum.

Enzyme therapy is based on the premise that the digestive deficiency in CD can be corrected by the oral administration of special enzymes formulated in enterically coated tablets so that 
the contents can be protected from the action of the gastric juices, allowing the required enzymes to pass through to the small intestine where they can complete the digestion of gluten peptides down to harmless small peptides and amino acids. It may not be necessary in some cases to enterically coat the tablet, as some enzymes such as the one from A.niger is stable at $\mathrm{pH} 2$ and is completely resistant to digestion with pepsin. However, its $\mathrm{pH}$ optimum is 4-5, which is well below that of the contents of the small intestine.

A totally different approach has been taken by Anderson et al. (2000). Since their discovery of a transglutaminase-modified peptide as the dominant A-gliadin T-cell epitope, these workers have pioneered the way for antigen-specific immunotherapy in CD. Using fresh peripheral blood lymphocytes from subjects undergoing challenge from gluten, interferon- $\gamma$ release was elicited by a 17-amino acid peptide corresponding to residues 57-73 of Agliadin. This peptide has the structure QLQPFPQPELPYPQPQS, with E at residue 65, being the result of deamidation of the corresponding glutamine residue.

It is interesting to note that tyrosine is present in this peptide as part of the PYPQ motif that could be important in relation to difficulty of proteolytic digestion. However, it will be important to consider sequences in the other coeliac-toxic cereals rye and barley, which feature PQQPY as being common in all three cereals implicated in CD (McLachlan et al., 2002).

If a suitable vaccine is able to be made, some liberties with respect to ingestion of gluten are expected to be allowed. However, the use of a safeguard based on enzyme therapy will probably still be necessary as the enzyme recommended is able to detoxify peptides that produce an immune response and also those that have cytotoxic action(Cornell et al.,2010) .

Plant enzymes were considered a better option than animal enzymes, despite the fact that the enzyme most likely to be missing or defective in $\mathrm{CD}$ is bound to be closely related to one from a higher animal. The reason for not continuing with our plans to market an animalbased product were due to the prevalence of animal diseases, such as bovine spongiform encephelopathy (BSE or "mad cow disease") and porcine adenoviruses. In addition, religious restraints put on products from these two animals in particular would be a barrier to their marketing. Other people may have dietary concerns. It was therefore decided to look at plant sources and among these were papaya latex, bromelain, chymotrypsin, fungal proteases and Aspergillus oryzae. These materials were compared against pure papain and prolyl endopeptidase.

It was found that papaya latex concentrate with a protection $(\mathrm{P} \%)$ of 93 was far the most active preparation. Crystalline papain, the major papaya enzyme, gave a P value of only 7 . Prolyl endopeptidase $(\mathrm{P}=35)$ gave results comparable to highly purified prolyl endopeptidase from Chryseobacterium meningosepticum, but in terms of specific activity, it was much lower than pure caricain, which gave a result of 9,412 (see later in this section).

The evaluation of these sources of enzymes for purpose of making an enzyme supplement to digest gliadin efficiently, was carried out using the rat liver lysosome assay (refer Section 2). Up until this stage, the assay was used for evaluation of the toxicity of gliadin peptides and for testing the residual toxicity (activity) after small intestinal mucosal digestion. By incubating the toxic gliadin digest with a sample of each enzyme, a comparison of the effectiveness of these enzymes could be made. A two hour period of incubation of the 
enzyme with the gliadin digest at $37^{\circ} \mathrm{C}$ was given before testing the residual activity of the gliadin against the lysosomes. Calculations of specific activity were also able to be made by dividing the protection $(\mathrm{P} \%)$ by the mass of enzyme-containing product.

The enzyme caricain (papaya protease omega) is a cysteine protease (Dubey et al., 2007) found in the latex of Carica papaya. Caricain is one of the several proteases present which degrade proteins. They are endopeptidases of broad and narrow specificity, with the major ones being papain, chymopapain, glycyl endopeptidase and caricain. They are synthesised by the plant as inactive forms (zymogens) that are converted into the active forms within a short time after the latex is removed from the plant (Azarkan et al., 2003).

The optimum $\mathrm{pH}$ of caricain is 6.8 and its isoelectric point is 10.5. As expected, it is eluted from cation exchangers such as SM Sephadex only at high concentrations $(>0.7 \mathrm{~mol} / \mathrm{L})$ of sodium chloride. It is classified internationally as E.C.3.4.22.30 and its function is that of an endopeptidase. The structure consists of a proenzyme of 106 amino acids and an active enzyme of 242 amino acids (Groves et al., 1996). Recent experiments with purified carciain indicated that the reaction which controls detoxification of a wheat gliadin digest at $\mathrm{pH} 7.5$ and $37^{\circ} \mathrm{C}$ is a 1 st Order reaction with rate constant $1.7 \times 10^{-4} \mathrm{sec}^{-1}$ (Cornell \& Stelmasiak, 2011). The enzyme was able to offer about $80 \%$ protection to rat liver lysosomes when used at a concentration of $1.7 \%$ on substrate after 2 hours incubation at $37^{\circ} \mathrm{C}$, representing a specific activity of 9,412 . These experiments were valuable in demonstrating that caricain is a very effective enzyme in detoxifying gliadin and promises to be a prime starting point for enzyme therapy. Papaya enzymes are deemed to be extremely safe (Australian Government Report, 2008) if extracted from the fruit of Carica papaya.

A further development in the use of papaya was the concept of synergism between two active enzymes. This was evident with combinations of the pig intestinal extract and the papaya latex. Table 3 shows that this combination showed a significant improvement over what would be expected from the mean protection ( $\mathrm{P} \%$ ) of two separate batches of pig intestinal extract and papaya latex. The experiment was repeated with bromelain but, in this case, there was nothing to be gained in protection although the combination gave higher protection than expected from the mean. There has been a report of combination enzyme therapy using prolylendopeptidase and an enzyme from germinating barley(Siegel et al.,2006) and this is worthy of further study with plant enzymes.

\begin{tabular}{|l|c|c|c|c|}
\hline Enzyme 1 & $\mathrm{P}(\%)$ & Enzyme 2 & $\mathrm{P}(\%)$ & Combination P(\%) \\
\hline Pig intestinal extract & 61 & Papaya latex & 71 & 92 \\
\hline Pig intestinal extract & 48 & Papaya latex & 54 & 68 \\
\hline Bromelain & 21 & Papaya latex & 62 & 61 \\
\hline
\end{tabular}

Note: Each enzyme evaluated at $6 \mathrm{mg} / \mathrm{mL}$ in mixture of two and also at $12 \mathrm{mg} / \mathrm{mL}$ separately. Results are the means of two determinations.

Table 3. Results of some combinations of crude enzymes to test for synergistic activity. The protection index $(\mathrm{P} \%)$ from the rat liver lysosome assay was used as the indicator.

\section{Preliminary clinical studies}

Clinical studies to confirm the value of enzyme therapy were of prime importance as only in vitro testing had been carried out up to the stage of using animal intestinal extracts. All the 
in vitro experiments had indicated that pig intestinal extracts completed the digestion of a toxic gliadin digest. The first trial was conducted to verify that these extracts could complete digestion in vitro. A large scale batch of pig intestinal extract was prepared for a clinical trial at The Royal Melbourne Hospital. This trial was carried out to test the efficacy of such an extract in countering the effects of a mild gluten challenge in patients with CD. Participants were 21 biopsy-proven adults with $\mathrm{CD}$ who were on a gluten-free diet. The design of the trial was of double-blind crossover type using the extract in enterically coated capsules and a placebo in the same type of capsules. Six patients were also biopsied and histological changes compared for treatment and placebo (Cornell et al., 2005).

In those patients who developed symptoms ( 8 of the 21 ) these symptoms were ameliorated with the enzyme $(p<0.02)$, suggesting that the therapy was beneficial. Further evidence was provided by the histological studies which showed that 5 of the 6 patients chosen at random showed small bowel abnormalities at the start of the trial, but that further damage as a result of the gluten challenge was reduced in 3 of these patients. Antibodies to tTG and gliadin (Dahele et al., 2001) were roughly correlated with severity of histological damage at the start of the trial but no significant reduction in titres was obtained during the course of the trial. This clinical trial was successful in demonstrating that the enzyme deficiency in coeliac disease could be partly corrected by the use of enzymes in a tablet administered orally at the start of a meal. As the tablets were enterically coated, it allowed the enzyme to pass through the stomach unaffected by the hydrochloric acid and pepsin present and to pass into the small intestine where it rapidly disintegates to release the enzymes for complete digestion of any small amount of gluten that may be ingested. In this way it acts as a safeguard and allows more latitude in selection of food. It will thus take the worry out of eating at restaurants, homes of friends and other places where there is a question about the gluten content of the food. It could represent the most important breakthrough in patient management since the introduction of the gluten-free diet over 50 years ago.

A further clinical trial is being conducted to evaluate histological changes in the small intestine of coeliac patients brought about by enzyme therapy using plant enzymes. The aim of this trial is to determine whether the active enzyme in papaya is able to repair damage small intestinal mucosa caused by small amounts of gluten in the diet. It will involve 20 biopsy-proven participants with CD who have been on a gluten-free diet for at least 12 months. Participants will undergo biopsy at the beginning and end of the test period (3 months) while taking either enterically coated tablets of a papaya oleo-resin extract or a placebo. Thus it is a double-blind design but without crossover and has a longer treatment period than the first trial, but without defined gluten challenge. As for the first trial, blood tTG levels are being monitored; participants with higher than normal levels have been favoured for this trial. Changes in small bowel histology during the course of treatment are the major indicators of whether the enzyme is effective, with confirmation from the examination of changes in the participants on placebo.

A combination of a gluten-free diet and enzyme therapy should ensure that traces of gluten in the diet are eliminated, thus providing a sound basis for maintaining the small intestine in sound condition. Otherwise, traces of gluten can bring about alterations in architecture of the small intestine, particularly in the region of the duodenum, and this is seen in a significant number of patients on a normal gluten-free diet without the benefit of enzyme therapy. In the light of experience, the use of such an enzyme safeguard is justified because 
it is well known that contamination alone makes the gluten content of coeliac diets doubtful. Added to that are the problems of inadequate labelling and the lack of knowledge of the disease by some food suppliers.

We are confident that enzyme supplementation will detoxify gluten in not only wheat, but also in rye, barley and oats. It will be a safer alternative than drugs and will be ready long before any other techniques can be implemented such as changing gluten into a non-toxic form or commercial production of a safe vaccine against gluten. We are convinced that our work with enzyme supplements is critical for the better management of coeliac disease and will reduce the incidence of ongoing intestinal dysfunction.

All of our work on digestion of gliadin is in complete agreement with the experiments of earlier workers, who found that the combined amino acids, present as building blocks in gluten, are not injurious to patients with gluten-sensitive enteropathy. It is extremely important to note that virtual complete digestion of gluten guarantees that there will be no adverse reaction to that mixture of amino acids and small peptides, in contrast to the disease state, where incompletely digested larger peptides are capable of causing damage by various mechanisms. The use of enzyme therapy is a significant step towards ensuring that these incompletely digested gluten peptides are at an absolute minimum concentration in the small bowel.

We are aware of other approaches to the problem of gluten ingestion but in the case of longterm solutions, there is still the likelihood of enzyme therapy being required as it targets all the toxic peptides, not just the immunoactive ones. Enzyme therapy will still be needed as a safeguard.

Early diagnosis of $\mathrm{CD}$ and enzyme therapy will safeguard against damage and consequences of long-term ingestion of gluten (osteoporosis, malabsorption of vital nutrients and lymphomas) and should reduce concerns about children and adults being uncertain of the gluten content of food, particularly that prepared outside the home.

Enzyme therapy provides a form of natural product therapy based on sound scientific principles for treatment of a number of conditions relating to gluten intolerance. It has further advantages of easy administration and its low cost could compensate for the extra costs of gluten-free foods, particularly if greater emphasis was placed on fruit, vegetables, meat and fish rather than gluten-free cakes and pastry. Gluten-free bread, cereals and pasta will need to be the main special foods purchased.

Enzyme therapy is now becoming well documented, although there is still a degree of scepticism, brought about by a strong leaning to the "immunological" theory of coeliac disease, rather than the older "enzyme deficiency" theory. Market trials are showing the value of a tablet containing the active enzyme, in that symptoms are markedly reduced. A significant percentage of coeliacs on a gluten-free diet are still experiencing symptoms of a mild to moderate nature and are thus risking further damage to their small intestine. Others with relatively few symptoms are certain to have some abnormalities in that region of the gut.

At present, we are considering commercialization of tablets manufactured to contain $300 \mathrm{mg}$ of crude papaya enzyme (15mg pure caricain) one of which is able to detoxify about $1.5 \mathrm{~g}$ gluten, about 5 dry cracker biscuits, or one third of a slice of bread. 


\section{Applications of enzyme therapy}

Enzymes are such versatile materials that their application to therapy should be widespread. Before enzyme therapy was considered for $C D$, enzymes were on the market for pancreatic insufficiency. Lipases, amylases and proteases are commonly present, in capsule or tablet form, that are useful for individuals with this condition. Pepsin, bromelain and papain are often used in conjunction with such enzymes to provide products that are useful as digestive supplements. For lactose deficiency, tablets containing the enzyme $(\beta-D-$ galactosidase) can be used or drops that can be added to milk or infant formulae. Apart from the present application of enzyme therapy to $C D$, there are other conditions where gluten is considered to be harmful and where a gluten-free diet is recommended. One such condition is dermatitis herpetiformis, in which the small intestine often shows only patchy damage, but the disease manifests itself as an itchy rash (Fry, 1992). A gluten-free diet is essential in order to prevent the troublesome rash but also to guard against damage to the small intestine. So far, we have been only able to test enzyme therapy with caricain in one individual and the results are promising insofar as the effects of a wheat-based cereal and bread were almost eliminated by the use of one tablet at the beginning of each breakfast meal. A small controlled clinical trial is now being planned.

Gluten may be a dietary factor in certain neurological disorders, e.g. schizophrenia. Dr Curtis Dohan was a pioneer of work on the harmful effects of gluten in schizophrenia. One study involved 110 patients, half of whom were on a diet free from cereal grains and milk. Those on the special diet showed improvement in their condition and were discharged almost twice as quickly (Dohan\&Grasberger, 1973).A subsequent trial showed that schizophrenics maintained on a cereal grain-free and milk-free diet regressed during a period of a "blind" gluten challenge (Singh\&Kay, 1976). The cause of these ill-effects appear to center around gluten peptides that act as opioids. (Fukudome \& Yoshikawa, 1992).

As schizophrenia is a very serious neurological illness, the use of enzyme therapy in conjunction with a gluten-free diet could be a useful form of patient management. If enzyme therapy and a gluten-free diet were used in conjunction with the medication it could turn out that the amounts of neuroleptic drugs used at present could be reduced, which would almost certainly mean less serious side effects.

Autism is another neurological condition which is often accompanied by gastrointestinal symptoms. Since the first report from Asperger (1961), who noted that many children with CD showed psychiatric conditions, there has been a strong focus on autism and its associated difficulties in intellectual and social development of the young. Because gluten contains many opioid sequences, these have again been thought to be a direct cause. In this condition and others with a neurological basis a gluten-free diet is helpful suggesting a role for enzyme supplementation.

Irritable bowel syndrome (Biesiekierski et al., 2011) is a condition in which abdominal pain, flatulence and bloating are commonly observed. It is commonly believed that wheat and/or gluten is responsible for many individuals with this condition and this has been largely responsible for the proliferation of many gluten-free foods. Better public education on CD has perhaps given the lead in this direction. However, those suffering from irritable bowel syndrome appear to outnumber those with $\mathrm{CD}$. 
Further work in this area will be undertaken to determine if enzyme therapy will be helpful. It may be successful in some individuals and not in others as there appear to be a number of dietary triggers in irritable bowel syndrome (Shepherd et al., 2008). Ulcerative colitis and Crohn's disease are examples of conditions where a gluten-free diet has been of some help, suggesting that enzyme therapy could be a useful adjunct treatment.

Another application of enzyme therapy could be in management of patients with silent CD. This condition is where the individual has villous atrophy yet displays no symptoms. Examples were provided by Matysiak-Budnik et al (2007) who studied individuals diagnosed with $C D$ in childhood but who were asymptomatic as adults on a normal diet. The majority (48/61) showed different degrees of villous atrophy (silent CD) while 13 had no detectable atrophy (latent $C D$ ). Latent patients did not differ significantly from the 7 control patients on a gluten-free diet, but did have CD-specific serum antibodies. However, this was not free of risk as 2 latent patients relapsed clinically and histologically on followup. The use of enzyme supplementation would be recommended in cases of silent $C D$ as otherwise risks of malignancy are raised, among other conditions. There is a wide range of symptoms and enteropathy caused by gluten (Picarelli et al., 1996).

Finally, mention should be made of the status of first degree relatives of patients with CD. The finding that $82.3 \%$ do not have CD (Biagi et al., 2008) is in keeping with general experience. However, it is likely that many of these individuals will have some intolerance, in keeping with their partial enzyme deficiency (Cornell \& Rolles, 1978) and therefore could be in the need of enzyme supplementation whilst on a normal or low gluten diet.

\section{Conclusions}

- Whether you agree with an enzyme deficiency in CD or simply believe that gliadin and certain other cereal proteins are difficult to digest down to non-toxic small peptides, enzyme therapy is an obvious answer to this problem. In our opinion it is the most useful advance in patient management since the gluten-free diet and deserves funding for further research. It could turn out to be a way of reversing damage to the small intestine caused by small amounts of gluten over extended periods of time.

- A significant proportion of patients with CD show minimal symptoms despite challenge with gluten and are in need of enzyme supplementation as a means of protecting them from intestinal damage. This applies particularly to those patients, who are regarded as having silent $\mathrm{CD}$ and therefore in need of early diagnosis and treatment. Otherwise, the consequences can be very serious (Maki\&Collin, 1997). Measurement of antibodies to tissue transglutaminase (tTG) is presently the most reliable diagnostic test with follow-up by biopsy (Van Heel \& West, 2006). Modern practice makes use of deamidated gliadin peptide assays.

- The use of extracts of pig intestinal mucosa confirmed that they were helpful in reducing the severity of symptoms induced in patients with CD (Cornell et al, 2006). This was taken to mean that such extracts were able to supply an enzyme or enzymes that were deficient in these patients. The enzymes in pig mucosa that make up for this deficiency are likely to be prolidases or oligoiminopeptidases capable of hydrolysing Nterminal peptide bonds associated with proline residues. Such residues are contained within motifs of amino acids that are associated with toxicity and are left intact after 
digestion with remission coeliac mucosa. Examples of these motifs are PQQPY, QQPYP found in wheat, rye and barley (Mc Lachlan et al.2002).

- The uses of enzymes from Carica papaya, especially caricain, seem to be effective in vitro tests. A highly purified caricain preparation has performed extremely well in these tests and has led to the setting up of a clinical trial to test the value of caricain in enzyme therapy (Cornell \& Stelmasiak, 2011).

- Enzyme therapy is expected to act as a safeguard and relieve those who suffer from $\mathrm{CD}$ from the worry of maintaining a strict gluten-free diet. Products of high potency should allow some latitude with oats, a very nutritious cereal, which is not part of a gluten-free diet in several countries. The immunotoxicity of oats has been shown to depend on the particular cultivar (Silano et al., 2002). Furthermore, it has been shown that there are three levels of antigenicity according to their reactivity to antibodies against the 33-mer peptide of an alpha-gliadin. High, medium and absent reactivity were observed, correlating with measured activation of T-lymphocytes from patients with CD and hence potential immunotoxicity. (Comino et al., 2011). Oat intolerance may be responsible for villous atrophy seen in patients who are eating oats but otherwise are adhering to a strict gluten-free diet (Arentz-Hansen et al., 2004).

- Although it is generally recognised that the function of HLA molecules is to present small peptides to T-cells, there is not a strong argument that HLA DQ2/DQ8 are primary causes of CD since a large proportion $25-30 \%$ of the Caucasian population also have this typing and do not have CD (Sollid, 2002). Instead, it is more reasonable to say HLA DQ2/DQ8 are predisposing factors and that the etiology is another genetic defect that manifests as an enzyme deficiency. Specific deamidation of a glutamine residue results in enhanced binding to those molecules and is important in the ensuing immunological reactions, but this probably only happens with peptides that have resisted digestion.

- $\quad$ CD has a wide spectrum of clinical presentation and mucosal damage. Furthermore it is spread widely throughout the world with it now being recognised in parts of the Orient (Jiang et al., 2009). It could now be regarded as a systemic disease because of its effect on the various organs of the body. Another aspect of the deleterious effect of gluten is the likely, but not always proven, effect in other disorders such as schizophrenia, autism, irritable bowel syndrome and other situations where individuals do not tolerate gluten (the so-called non-coeliac gluten intolerance).

- At the molecular level, there has been much progress in our understanding of those parts of the gliadin molecule that are the cause of further reactions that damage the small intestinal mucosa. Two regions of the A-gliadin molecule that remain undigested by remission coeliac mucosa are peptides from residues 12-19 and 77-84 and the problems seem to center around motifs associated with toxicity such as PSQQ, QQQP and QQPY. It should be noted that QQPYP and PQQPY are present in all three coeliactoxic cereals - wheat, rye and barley (McLachlan et al., 2002).

- $\quad$ There appears to be a great need for enzyme therapy as a form of management in CD. It will reduce the worry connected with the necessity of keeping to a strict gluten-free diet, particularly when the food has been prepared outside the home or where contamination by wheat, rye or barley products is a possibility. By the use of a natural enzyme from the papaya plant, this should be able to be accomplished safely. However, clinical trials will be the arbiter of this project. 
- The availability of new, highly sensitive and specific serological tests has led to the realization that $\mathrm{CD}$ is the most common food intolerance in the world (Accomando \& Cataldo, 2004). We have always been aware of the need to understand the mechanisms that operate in this disease and resulting from these studies was the investigation of animal and plant enzymes as a form of therapy (Cornell \& Stelmasiak, 2009). Coupled with this advance is the need for diagnosis of $\mathrm{CD}$ at an early age, making enzyme therapy an important lifetime management program. We think enzyme therapy is ready for "prime time".

\section{References}

Accomando, S. \& Cataldo, F. (2004). The global village of coeliac disease. Dig. Liver Dis. Vol. 36. pp.492-498.

Alfonso, P., Soto, C., Albar, J.P., Camafeita, E., Escobar, H., Suárez, L., Rico, M., Bruix, M., \& Méndez, E. (1998). Beta structure motif recognition by anti-gliadin antibodies in coeliac disease. FEBS letters. Vol. 427. pp. 36-40.

Anderson, C.M., Fraser A.C., French J.M., Gerrard J.W., Sammons, H.G. \& Smellie, J.M. (1952). Coeliac disease: gastrointestinal studies and the effect of dietary wheat flour. Lancet. Vol.1. pp. 836-842.

Anderson, R. P., Degano, P., Godkin, A.J., Jewell, D.P. \& Hill, A.V. (2000) In vivo antigen challenge in coeliac disease identifies a single transglutaminase-modified peptide as the dominant A-gliadin T-cell epitope. Nature Med. Vol. 6. pp. 337-342.

Arentz-Hansen, H., Fleckenstein, B., Molberg, Ø., Scott, H., Koning, F., Jung, G., Roepstorff, P., Lundin, K., \& Sollid, L. M. (2004). The molecular basis for oat intolerance in coeliac disease patients. PLoS Med. Vol.1. pp. 84-92.

Arnon, R. (1970). The cysteine proteases: papain. Methods Enzymol. Vol. 19. pp. 226-244.

Australian Government Report. (2008). The biology of Carica Papaya L. Dept. of Health Report. Version 2. pp. 25-26.

Azarkan, M., El Moussaoui, A., Van Wuytswinkel, D., Dehon, G. \& Looze, Y. (2003) Fractionation and purification of the enzymes stored in the latex of Carica papaya. J Chromatog.B Vol. 790. pp. 229-238.

Biagi, F., Campanella, J., Bianchi, P.I., Zanellati, G., Capriglione, I., Klersy, C. \& Catassi, C., Fabiani, E., Iacono, G., D'Agate, C., Francavilla, R., Biagi, F., Volta, V., Accomando, S., Picarelli,A., De Vitis, I., Pianelli, G., Gesuita, R., Carle, F., Mandolesi, A., Bearzi, I. \& Fasano, A. (2007). A prospective, double-blind, placebo-controlled trial to establish a safe gluten threshold for patients with coeliac disease. Am J Clin Nutr. Vol. 85. pp.160-166.

Biagi, F., Zimmer, K.P., Thomas, P.D., Ellis, H.J. \& Ciclitira, P. (1999). Is gliadin misrepresented to the immune system in coeliac disease? A hypothesis. Q J Med. Vol.92. pp. 119-122.

Biesiekierski, J.R., Newnham, E.D., Irving, P.M., Barrett, J.S., Haines, M., Doecke, J.D., Shepherd, S.J., Muir, J.G. \& Gibson, P.R. (2011). Gluten causes gastrointestinal symptoms in subjects without coeliac disease: a double-blind randomized placebocontrolled trial. Am J Gastroenterol. Vol. 106. pp. 508-514.

Bjarnason, I. \& Peters, T.J. (1983). A persistent defect in small intestinal permeability in coeliac disease demonstrated by a 51-Cr-labelled EDTA absorption test. Lancet. Vol. 1. pp. 323-325. 
Bronstein, H.D., Haeffner, L.J., \& Kowlessar, O.D. (1966). Enzymatic digestion of gliadin: The effect of the resultant peptides in adult coeliac disease. Clin Chim Acta. Vol.14. pp.141-155.

Burgin-Wolff, A., I. Dahlbom, F. Hadziselimovic, \& C. J. Petersson. (2002). Antibodies against human tissue transglutaminase and endomysium in diagnosing and monitoring coeliac disease. Scand J Gastroenterol. Vol. 37. pp. 685-691.

Comino, I., Real, A., de Lorenzo L, Cornell H, López-Casado MÁ, Barro F, Lorite P, Torres MI, Cebolla A, Sousa C. (2011). Diversity in oat potential immunogenicity: basis for the selection of oat varieties with no toxicity in coeliac disease. Gut. Vol. 60. pp. 915-922.

Corazza, G.R. (2008 The incidence of coeliac disease in adult first degree relatives. Dig Liver Dis. Vol.40. pp. 97-100.

Cornell, H.J. (1974). Circulating antibodies to wheat gliadin fractions in coeliac disease. Arch Dis Child. Vol. 49. pp. 454-458.

Cornell, H.J. (1996). Coeliac disease: A review of the causative agents and their possible mechanisms of action. Amino Acids, Vol. 10. pp. 1-19.

Cornell, H.J. (1998). Partial in vitro digestion of active gliadin-related peptides in coeliac disease. J Protein Chem. Vol. 17. pp. 739-744.

Cornell, H. J., Auricchio, R. S., Ritis, G. De, Vincenzi, M. De, Maiuri, L., Raia, V. \& Silano, V. (1988) Intestinal mucosa of coeliacs in remission is unable to abolish toxicity of gliadin peptides on in vitro developing fetal rat intestine and cultured atrophic coeliac mucosa. Pediatric Research. Vol. 24, pp. 233- 237.

Cornell, H.J., Doherty, W. \& Stelmasiak T. (2010). Papaya enzymes capable of detoxification of gliadin. Amino Acids. Vol.38. pp. 165-175.

Cornell, H. J. \& Hoveling, A. W. (1998). In: Wheat chemistry and utilization. pp.350-360. Technomic Publishing Company, Inc. Lancaster, PA, U.S.A., ISBN 1-56676-348-7.

Cornell, H.J., Macrae, F.A., Melny, J. Pizzey, C., Cook, F., Mason, S., Bhathal, P.\& Stelmasiak, T. (2005). Enzyme therapy for management of coeliac disease. Scand. J. Gastroent. Vol.40.pp. 1304-1312.

Cornell, H.J., Mothes, T. (1993) The activity of wheat gliadin peptides in in vitro assays for coeliac disease. Biochim Biophys Acta ; Vol. 1181. pp. 169-173.

Cornell, H.J. , Mothes, T. (1995) Further studies of the in vitro activity of synthetic gliadin peptides in coeliac disease. Biochim Biophys Acta. Vol.1270. pp. 168-172.

Cornell, H.J., \& Rivett, D.E. (1995). In vitro mucosal digestion of synthetic gliadin-derived peptides in coeliac disease. J Protein Chem. Vol. 14. pp. 335-339.

Cornell, H.J. \& Rolles, C.J. (1978). Further evidence of a primary mucosal defect in coeliac disease. Gut. Vol.19. pp. 253-259.

Cornell, H.J. \& Stelmasiak, T. (2004) Enzyme supplementation in coeliac disease.Proceedings of the $11^{\text {th }}$ International Symposium on Coeliac Disease. Belfast, Northern Ireland. p.196.

Cornell, H.J. \& Stelmasiak T. (2007). A unified hypothesis of coeliac disease with implications for management of patients. Amino Acids. Vol. 33, pp.43-49.

Cornell, H.J. \& Stelmasiak, T. (2009). Strategies for improved outcomes for those with coeliac disease. In: Coeliac Disease: Etiology, Diagnosis and Treatment. M.A. Edwards, (Ed).pp. 207-211. ISBN: 978-1-61209-873-9., Nova Science Publishers Inc., N.Y.

Cornell, H.J. \& Stelmasiak, T. (2011) Caricain a basis for enzyme therapy for coeliac disease. Sth Afr J Sci. Vol.9/10. pp.107-111.

Cornell, H.J. \& Townley, R.R.W. (1973a). Investigating possible intestinal peptidase deficiency in coeliac disease. Clin Chim Acta. Vol.43. pp.113-125.

Cornell, H.J. \& Townley, R.R.W. (1973b). The effect of gliadin peptides on rat-liver lysosomes in relation to the pathogenesis of coeliac disease. Clin ChimActa. Vol.49. pp.181-188. 
Cornell, H.J. \& Townley, R.R. (1974). The toxicity of certain cereal proteins in coeliac disease. Gut. Vol.15. pp. 862-869.

Cornell, H.J., Skerritt, J.H., Puy, R. \& Javadpour, M. (1994). Studies of in vitro Y - interferon production in coeliac disease as a response to gliadin peptides. Biochim Biophys Acta; Vol.1226. pp.126-130.

Cornell, H.J., Wieser, H. \& Belitz, H.D. (1992). Characterisation of the gliadin-derived peptides which are biologically active in coeliac disease. Clin Chim Acta. Vol. 213. pp. 37-50.

Cornell, H.J. \& Wills-Johnson, G. (2001). Structure-activity relationships in coeliac-toxic gliadin peptides. Amino Acids. Vol. 21. pp. 243-253.

Dahele, A.V., Aldhous, M.C., Humphreys, K., \& Ghosh, S. (2001). Serum IgA tissue transglutaminase antibodies in coeliac disease and other gastrointestinal diseases. Q J Med. Vol.94. pp. 195-205.

De Ritis, G., Auricchio, S., Jones, H.W.,Lew, E.J.L., Bernardin, J.E. \& Kasarda, D. (1988). In vitro (organ culture) studies of the toxicity of specific A-gliadin peptides in coeliac disease. Gastroenterology. Vol. 94, pp. 41-49.

Dicke, W.K., Wejiers, H.A., and van de Kamer, J.H. (1953). Coeliac disease. II. The presence in wheat of a factor having a deleterious effect in cases of coeliac disease. Acta Paediatrica, Vol. 42, pp. 34-42.

Dohan, F.C. \& Grasberger, J.C. (1973). Relapsed schizophrenics: earlier discharge from the hospital after cereal-free, milk-free diet. Am J Psychiatry Vol.130. pp. 685-688.

Dolly, J.O. \& Fottrell, P.F. (1969). Effect of different peptide fractions from wheat gliadin on rat liver lysosomes. Irish J Med Sc. Vol. 2. p. 47.

Donlon, J., \& Stevens, F.M. (2004). No lack of prolyl oligopeptidase (POP) in the coeliac mucosa. Proceedings of the $11^{\text {th }}$ International Symposium on Coeliac Disease. Belfast, Northern Ireland. p.19.

Drago, S., El Asmar, R., Di Pierro, M.,Clemente, G. M., Tripathi, A., Sapone, A., Thakar, M., Iacono, G., Carroccio, A., D'Agate, C., Not, T., Zampini, L., Catassi, C. \& Fasano A. (2006). Gliadin, zonulin and gut permeability: Effects on coeliac and non-coeliac intestinal mucosa and intestinal cell lines. Scand J Gastroenterol.. Vol.41. pp. 408-419.

Dubey, V.K., Pande, M., Singh, B.K., \& Jagannadham, M.V. (2007). Papain-like proteases: applications of their inhibitors. Afr J Biotechnol. Vol. 6. pp. 1077-1086.

Fry, L. (1992). Dermatitis herpetiformis. In: Coeliac disease, M. Marsh, (Ed.), Oxford, UK, Blackwell Scientific Pub.

Falchuk, Z.M. \& Strober, W. (1974). Gluten sensitive enteropathy: synthesis of anti-gliadin antibody in vitro. Gut. Vol. 15. pp. 947-952.

Frazer, A.C., Fletcher, R.F., Ross, C.A.C., Shaw, B., Sammons, H.G. \& Schneider, R. (1959). Gluten-induced enteropathy: The effect of partially digested gluten. Lancet. Vol. 274. pp. 252-255.

Fukudome, S.I., \& Yoshikawa , M. (1992). Opioid peptides derived from wheat gluten: Their isolation and characterization. FEBS letters. Vol.296. pp.107-111.

Gravett, P.S.,Viljoen,C. \& Osthvizen, M. (1991). A steady-state kinetic analysis of the reaction between arginine esterase E-I from Bitis Gabonica venom and synthetic arginine substrates and the influence of $\mathrm{pH}$, temperature and solvent deuterium isotope. In. J Biochem. Vol. 23. pp. 1085-1099.

Groves, M. R., Taylor, M. A., Scott, M., Cummings, N. J., Pickersgill, R. W. \& Jenkins, J. A. (1996). The prosequence of procaricain forms an a-helical domain that prevents access to the substrate-binding cleft. Structure. Vol.4.pp. 1193-1203. 
Halstensen, T.S., Scott, H., Fausa, O. \& Brandtzaeg, P., (1993). Gluten stimulation of coeliac mucosa in vitro induces activation (CD25) of lamina propria CD4+ T cells and macrophages but no crypt cells hyperplasia. Scand J Immunol. Vol. 38. pp. 581-590.

Hausch, .F, Shan, L., Santiago, N.A., Gray, G.M. \& Khosla, C: Intestinal digestive resistance of immunodominant gliadin peptides. Am J Physiol Gastrointest Liver Physiol. (2002). Vol. 283. pp. G996-G1003.

Lucarelli, S., Frediani, T., Zingoni, A.M., Ferruzzi, F., Giardini, O., Quintieri, .F, Barbato, M., D'Eufemia, P. \& Cardi, E. (1995). Food allergy and infantile autism. Panminerva Med. Vol.37. pp.137-141.

Jiang, L.L., Zhang, B.L. \& Liu, Y.S. (2009). Is adult coeliac disease really uncommon in Chinese? J Zhejiang Univ Sci. B. Vol. 10. pp. 168-171.

Jones VA, McLaughlan P, Shorthouse M, Workman E, Hunter JO. (1982) Food intolerance: a major factor in the pathogenesis of irritable bowel syndrome. Lancet. Vol.2. pp.11151117.

Kagnoff M. (2007) Coeliac disease: pathogenesis of a model immunogenetic disease. J Clin Invest. Vol.117. pp.41-49.

Kasarda, D.D., Okita, T.D., Bernardin, J.E., Baecker, P.A., Nimmo, C.C., Lew, E.J.L., Dietler, M.D. \& Greene, F.C. (1984). Nucleic acid (cDNA) and amino acid sequences of ÿ-type gliadins from wheat (Triticum aestivum). Proc Natl Acad Sci USA. Vol. 81. pp. 4712-4716.

Kocna, P., Fric, P.,Slabý, J.\& Kasafírek, E. (1980). Endopeptidase of the brush border membrane of rat enterocyte: separation from aminopeptidase and partial characterization. Hoppe-Seyler Z Physiol Chem. Vol. 361. pp.1401-1412.

Kocna, P., Mothes, T., Krchnak, V. \& Fric. P. (1991) Relationship between gliadin peptide structure and their effect on the foetal chick duodenum. Z. Lebensm. Unters. Forsch. Vol. 192. pp. 116-119.

Riecken, A.O., Stewart, J.S., Booth, C.C. \& Pearse, A.G.E. (1966). A histochemical study of the role of lysosomal enzymes in idiopathic steatorrhoea before and during a gluten-free diet. Gut. Vol.7. pp.317-332.

Mäki, M. (1996). Coeliac disease and autoimmunity due to unmasking cryptic epitopes. Lancet. Vol.348. pp.1046-1047.

Mäki, M. \& Collin, P. (1997). Coeliac disease. Lancet, Vol. 349, pp.1755-1759.

Matysiak-Budnik, T., Candalh, C., Cellier, C., Dugave, C., Namane, A., Vidal-Martinez, T., Cerf-Bensussan, N. \& Heyman, M. (2005). Limited efficiency of prolylendopeptidase in the detoxification of gliadin peptides in coeliac disease. Gastroenterology. Vol.129. pp.786-796.

Matysiak-Budnik, T., Malamut, G., de Serre, N.P., Grosdidier, E., Seguier, S., Brousse, N., Caillat-Zucman, S., Cerf-Bensussan, N., Schmitz, J. \& Cellier, C. (2007). Long-term follow-up of 61 coeliac patients diagnosed in childhood: evolution toward latency is possible on a normal diet. Gut. Vol.56. pp. 1379-1386.

Mantzaris, G.J., \& Jewell, D.P. (1991). In-vivo toxicity of a synthetic dodecapeptide from Agliadin in patients with coeliac disease. Scand J Gastroenterol. Vol. 26. pp. 392-398.

McAdam, S.N. E Sollid LM. (2000). Getting to grips with gluten. Gut. Vol. 47. pp. 743-745.

McLachlan, A., Cullis, P.G., Cornell, H.J. (2002) The use of extended motifs for focussing on toxic peptides in coeliac disease. J Biochem Mol Biol Biophys. Vol. 6. pp. 319-324.

Molberg, O., Mcadam, S.N., Korner, R., Quarsten, H., Kristiansen, C., Madsen, L., Fugger, L., Scott, H., Noren, O., Roepstorff, P., Lundin, K.E., Sjostrom, H. \& Sollid, L.M. (1998). Tissue transglutaminase selectively modifies gliadin peptides that are recognized by gut-derived T cells in coeliac disease. Nat Med. Vol.4. pp.713-717. 
Monsuur, A.J., de Bakker, P.I.W., Alizadeh, B.Z., Zhernakova, A., Bevova, M.R., Strengman, E., Franke, L., van't Slot, R., van Belzen, M.J., Lavrijsen, I.C.M. et al. (2005). Nature Genetics. Vol.37. p.1341-1344.

Mothes, T., Osman, A.A., Seilmeier, W. \& Wieser, H. (1999). The activity of single gliadin components in a foetal chick intestine assay for coeliac disease. Eur Food Res Technol. Vol. 210. pp. 93-96.

Mothes, T., Muhle, W., Muller, F. \& Herkens, W.T.J.M. (1985). Influence of gliadin on fetal chick intestine in tissue culture. Biol Neonate. Vol.48. pp.59-Shan, L., Molberg, Ø., Parrot, I., Hausch, F., Filiz, F., Gray, G.M., Sollid, L.M. \& Khosla, C. ( 2002.) Structural basis for gluten intolerance in coeliac sprue. Science. Vol. 297. pp. 2275-2279.

Sealy-Voyksner, J. A., Khosla, C., Voyksner, R. D. \& Jorgensen, J. W. (2010). Novel aspects of quantitation of immunologenic wheat gluten peptides by liquid chromatographymass spectrometry/mass spectrometry. J.Chromatogr A. Vol.25, pp. 4167-4183.

Siegel, M., Bethune, M. T., Gass, J., Ehren, J., Xia, J., Johannsen, A., Stuge, T. B., Gray, G. M., Lee, P. P. \& Khosla, C. (2006). Rational design of combination enzyme therapy for coeliac sprue. Chem Biol. Vol. 13, pp. 637-647.

Silano, M., Di Benedetto, R., Maialetti, F., De Vincenzi, A., Calcaterra, R., Cornell, H.J. \& De Vincenzi, M. (2007). Avenins from different cultivars of oats elicit response by coeliac peripheral lymphocytes. Scand J Gastroenterol.Vol. 42. pp.1302-1305.

Singh, M.M. \& Kay, S.R. (1976). Wheat gluten as a pathogenic factor in schizophrenia. Science. Vol. 191. pp. 401-402.

Shepherd, S,J., Parker, F.C., Muir, J.G. \& Gibson, P.R. (2008) Dietary triggers of abdominal symptoms in patients with irritable bowel syndrome: randomized placebocontrolled evidence. Clin Gastroenterol Hepatol. Vol. 6. pp. 765-771.

Shan, L.,Molberg, Ø., Parrot, I., Hausch, F., Filiz, F., Gray, G.M., Sollid, L.M. \& Khosla, C. (2002). Structural basis for gluten intolerance in coeliac sprue. Science. Vol. 297. pp. 2275-2279.

Shuppan,D., Junker, Y. \& Barisani, D. (2009). Coeliac disease: from pathogenesis to novel therapies. Gastroenterology. Vol. 137. pp. 1912-1933.

Shuppan, D. \& Hahn, E.G. (2002). Gluten and the gut - lessons for immune regulation. Science. Vol.297. pp. 2218-2220.

Sollid, L.M. (2002). Coeliac disease: Dissecting a complex inflammatory disorder. Nature Reviews Immunology. Vol.2, pp. 647- 655.

Stepniak, D., Spaenij-Dekking, L., Mitea, C., Moester, M., de Ru, A., Baak-Pablo, R., van Veelen, P., Edens, L. \& Koning F. (2006). Highly efficient gluten degradation with a newly identified prolyl endoprotease: implications for coeliac disease. Am J Physiol Gastrointest Liver Physiol . Vol. 291. pp. G621-G629.

Storch, W. (1978). About the differentiation of antibodies against the connective tissue. Acta Histochem. Vol.62. pp. 57-67.

Sturgess, R., Day, P., Ellis, H.J., Lundin, K.E., Gjertsen, H.A., Kontakou, M. \& Ciclitira, P.J. (1994). Wheat peptide challenge in coeliac disease. Lancet. Vol. 343.pp. 758-761.

Townley, R.R.W., Bhathal, P.S., Cornell, H.J. \& Mitchell, J.D. (1973). Toxicity of wheat gliadin fractions in coeliac disease. Lancet. Vol.1. pp.1363-1364.

Vader, W., Kooy, Y., van Veelen, P., de Ru, A., Harris, D., Benckhuijsen, W.,Pena, S., Mearin, L., Drijfhout, J.W. \& Koning, F. (2002). The gluten response in children with coeliac disease is directed toward multiple gliadin and glutenin peptides. Gastroenterology. Vol. 122. pp. 1729-1737.

Van Heel, D.A. \& West J. (2006). Recent advances in coeliac disease. Gut, Vol.55, pp. 1037-1046.

Weissmann, G. (1964). Lysosomes, autoimmune phenomena, and diseases of connective tissue. Lancet. Vol. 284, pp. 1373 - 1375. 
(C) 2012 The Author(s). Licensee IntechOpen. This is an open access article distributed under the terms of the Creative Commons Attribution 3.0 License, which permits unrestricted use, distribution, and reproduction in any medium, provided the original work is properly cited. 